\title{
Translation, Cultural Adjustment and Evaluation of Reliability and Validity of "Quality of Life Enjoyment and Satisfaction Questionnaire - Short Form" for Patients with Schizophrenia
}

\author{
Aleksandra Petrović-Kitić, Slobodan Janković \\ University of Kragujevac, Faculty of Medical Sciences, Department of Pharmacology and Toxicology, Kragujevac, \\ Serbia
}

\begin{abstract}
SUMMARY
The Quality of Life Enjoyment and Satisfaction Questionnaire - Short Form is the most often used scale for measuring the quality of life of patients with psychiatric diseases. The aim of this research was to analyze the possibilities for measuring the quality of life in clinical conditions on the sample of patients with schizophrenia by using this scale. The study was conducted on the group including 153 patients with schizophrenia at the Institution for Accommodation of Adults "Male Pčelice", Kragujevac. The study was observational and cross-sectional. The reliability of questionnaire was examined by using Cronbach's alpha. The two tests of factor analysis adequacy were used, Spherical Bartlett's Test and Keiser-Meyer-Olkin test (sampling adequacy). Validation was performed by calculating the correlation (validation by criteria). The Quality of Life Enjoyment and Satisfaction Questionnaire - Short Form was reliable (Cronbach's alpha coefficient was 0.730 ) and valid. According to Catell criterion two domains were applied. This two-component solution explained the total of $37.80 \%$ variance, whereby the contribution of the first domain was $\mathbf{2 7 . 1 \%}$ and the second $\mathbf{1 0 . 7 \%}$. The Quality of Life Enjoyment and Satisfaction Questionnaire - Short Form is suitable for everyday clinical evaluation of the patients with schizophrenia.
\end{abstract}

Key words: quality of life, questionnaires, cultural adjustment, reliability

Corresponding author:

Aleksandra Petrović-Kitić

E-mail:aleksandra-ph@hotmail.com 


\section{INTRODUCTION}

Schizophrenia is a chronic disease characterized by the loss of contact with reality. Its symptoms are clinically manifested as hallucinations, disorganised thinking and disorganised behaviour, social and emotional withdrawal and deficit of cognitive functions (1). Lately, a great interest in the quality of life (QoL) of patients with schizophrenia and other psychiatric diseases has been increasingly developed, since it was necessary to complete the data on the influence of the disease and therapeutic efficiency and selection of appropriate medication on their QoL (2). Quality of life includes physical, psychological and social domains characterised by individualism, since everyone experiences own QoL as specific (3). World Health Organisation defined QoL as perception of an individual of own position in life in the context of culture and system of values in their environment including their own aims, expectations, standards and interests (4).

The Quality of Life Enjoyment and Satisfaction Questionnaire (Q-LES-Q) is the most often used scale for measuring QoL of patients with psychiatric diseases. Based on the interview with patients, the questionnaire evaluated their physical health, individual feelings, ability for leisure time activities, social relationships, daily life activity, satisfaction with medication and overall satisfaction in life (5). The Quality of Life Enjoyment and Satisfaction Questionnaire - Short Form (Q-LES-Q-SF) is a short version of a long scale. This version completely evaluates QoL of psychiatric patients concerning good reliability, validity and sensitivity (6-8).

The aim of this research was to analyze the possibilities of measuring QoL of the patients with schizophrenia in clinical conditions by using the Quality of Life Enjoyment and Satisfaction Questionnaire - Short Form and to reveal a possible correlation between the score of Quality of Life Enjoyment and Satisfaction Questionnaire - Short Form and score of World Health Organisation Questionnaire - Short Form.

\section{MATERIAL AND METHODS}

\section{Quality of Life Enjoyment and Satisfac- tion Questionnaire - Short Form}

The Quality of Life Enjoyment and Satisfaction Questionnaire - Short Form is based on the patients answers during the interview; it includes 16 items derived from the original long scale with 93 items. This scale evaluates the total QoL and satisfaction with physical health, mood, abilities to perform everyday activities, leisure time activities, household activities, social and family relationships, sexual performance, functioning in daily life, economic status, overall sense of wellbeing and daily intake of medication. The answers were scored from 1 to 5 , where 1 denoted very poor, 2 denoted poor, 3 denoted fair, 4 denoted good and 5 was very good QoL during the past week. Higher score pointed to better QoL and satisfaction with life.

The scoring of Quality of Life Enjoyment and Satisfaction Questionnaire - Short Form involves summing of only first 14 items to yield a raw total score. The last two items are not included in the total score. The last items are standalone, related to the satisfaction with medication and overall life satisfaction and contentment and they are not incorporated in the total score. The raw total score ranges from 14 (minimum) to 70 (maximum). The raw total score is transformed into a percentage maximum possible score using the instructions and table provided by the author of the scale (5).

The Quality of Life Enjoyment and Satisfaction Questionnaire - Short Form was translated according to international translation standards and transcultural adjustment of questionnaires: double translation from English into Serbian, harmonization of translation, re-translation from Serbian into English, adjustment of final translation and pilot testing of the translation on the group of eight study participants (9). The questionnaire was also validated by the panel of psychiatrists at the Institution for Accommodation of Adults "Male Pčelice", Kragujevac.

\section{Population and sampling}

The study was conducted at the Institution for Accommodation of Adults "Male Pčelice", Kragujevac. The study included all patients suffering from schizophrenia diagnosed by the tenth International Classification of Diseases (10) who were not deprived of business abilities. The total number of patients who participated in the study was 153 . The patients with mental retardation and cognitive disorders that prevented them from understanding and answering the offered questionnaires, illiterate patients and those with sight disorders and dementia 
were excluded from the study. Each patient received the information related to the participation in the study in oral and written form.

By insight into medical documentation and through the interview with patients, their age, gender, education, diagnosis, length of stay at the institution and year of beginning of disease were obtained. Conducting of the study received the approval of competent Ethical Committee at the Institution for Accommodation of Adults "Male Pčelice" and Ministry of Labour and Social Policy.

The study was observational, of cross-sectional type. All the members of the population who fulfilled the criteria for inclusion and exclusion were examined.

\section{Scale reliability}

After the patients filled in the questionnaire, the results were entered into SPSS table and then the reliability of questionnaire was examined by calculating the Cronbach's alpha.

\section{Factor analysis}

Factor analysis was done in order to identify a small set of factors which shows internal bonds in the group of linked variables (11). The two tests of adequacy of factor analysis were used, Spherical Bartlett's Test and Keiser-Meyer-Olkin test of sampling adequacy. Spherical Bartlett's Test should be statistically significant $(p<0.05)$ to justify the application of factor analysis. Keiser-Meyer-Olkin indicator ranges between 0 and 1 , hence 0.6 is recommended as the smallest sum acceptable for good factor analysis. To make the scale acceptable for factor analysis, correlation matrix should have at least a part of correlations higher than 0.3 (12). Then, the selection of a smaller number of factors was made, i.e. the determination of the smallest number of factors which properly represented interconnections in the set of variables. Keiser's criterion or the criterion of characteristic values was used. Only those factors whose characteristic values were higher than 1.0 were taken for further analysis. The number of factors was determined also by Catell criterion (criterion of the Scree plot) i.e. only the factors above the curve "elbow" were taken into account since they best contributed to the explanation of variance in the set of data. When the number of factors was defined, the factors were rotated in order to be explained successfully. To minimize the number of variables with high absolute values of factor weights, Varimax method of orthogonal rotation was used.

\section{Validation}

As it was stated, the questionnaire was validated by the panel of psychiatrists at the Institution for Accommodation of Adults "Male Pčelice" Kragujevac. The correlation between the score of the Quality of Life Enjoyment and Satisfaction Questionnaire - Short Form and the score of the previously translated World Health Organization Questionnaire - Short Form was examined. The validation was also done by calculation of the correlation (validation by criterion). SPSS Windows, version 18.0 was used for statistical data processing.

\section{RESULTS}

\section{Population}

The study included 153 patients. General characteristics of study participants are presented in Tables 1 and 2.

\section{Reliability of the scale}

The Quality of Life Enjoyment and Satisfaction Questionnaire - Short Form had good intrinsic agreement and Cronbach's coefficient alpha of 0.730 .

\section{Factor analysis}

Sixteen items of the Quality of Life Enjoyment and Satisfaction Questionnaire - Short Form were subject to principal component analysis. Before the principal component analysis was done, the relevance of data for factor analysis was evaluated. The examination of correlation matrix revealed numerous coefficients of 0.3 and more. The value of KeiserMeyer-Olkin indicator was 0.794 which exceeded the recommended value of 0.6. Spherical Bartlett's test reached statistical significance $\left(\chi^{2}=622.172 ; \mathrm{df}=120\right.$; $\mathrm{p}<0.000)$. The principal component analysis revealed the presence of 5 domains with eigenvalues over 1 , which explain $27.1 \%, 10.7 \%, 8.7 \%, 7.8 \%$ and $6.4 \%$ variances. These 5 domains explain the total of 60.82 $\%$ of variance. The examination of diagram curve revealed clear point of curve after the first domain. In accordance with Catell criterion, it was decided 
Table 1. General characteristics of study participants

\begin{tabular}{l|c|c|c}
\hline \hline Characteristic & Groups & Number of patients & Percentage \\
\hline \multirow{3}{*}{ Gender } & Males & 84 & 54.9 \\
\hline \multirow{4}{*}{ Education } & Females & 69 & 45.1 \\
\cline { 2 - 4 } & No education & 10 & 6.5 \\
\cline { 2 - 4 } & Primary school & 52 & 34.0 \\
\cline { 2 - 4 } & Secondary school & 79 & 51.6 \\
\hline \multirow{4}{*}{ Diagnosis } & University degree & 12 & 7.8 \\
\cline { 2 - 4 } & Residual schizophrenia & 25 & 16.3 \\
\cline { 2 - 4 } & Paranoid schizophrenia & 24 & 14.7 \\
\cline { 2 - 4 } & Hebephrenic schizophrenia & 22 & 25.5 \\
\cline { 2 - 4 } & Inorganic mental disease & 39 & 28.1 \\
\cline { 2 - 4 } & Simple schizophrenia & 43 & \\
\hline \hline
\end{tabular}

Table 2. General characteristics of study participants

\begin{tabular}{l|c|c|c|c|c}
\hline \hline \multicolumn{1}{c|}{ Characteristic } & $\begin{array}{c}\text { Number of } \\
\text { patients }\end{array}$ & $\begin{array}{c}\text { Minimum } \\
\text { value }\end{array}$ & $\begin{array}{c}\text { Maximum } \\
\text { value }\end{array}$ & $\begin{array}{c}\text { Arithmetic } \\
\text { mean }\end{array}$ & $\begin{array}{c}\text { Standard } \\
\text { deviation }\end{array}$ \\
\hline Age & 153 & 20 & 77 & 50.78 & 10.09 \\
\hline $\begin{array}{l}\text { Year of the beginning } \\
\text { of disease }\end{array}$ & 153 & 10 & 57 & 28.48 & 10.10 \\
\hline $\begin{array}{l}\text { Length of stay at the } \\
\text { institution (years) }\end{array}$ & 153 & 1 & 39 & 14.56 & 9.74 \\
\hline \hline
\end{tabular}

Table 3. Values of information by items and their domains

\begin{tabular}{|c|c|c|c|c|c|}
\hline \multirow{2}{*}{ Items } & \multicolumn{5}{|c|}{ Domains and values of information } \\
\hline & 1 & 2 & 3 & 4 & 5 \\
\hline $\begin{array}{l}\text { Taking everything into consideration during the past } \\
\text { week, how satisfied were you with your physical health? }\end{array}$ & 0.633 & & & & \\
\hline $\operatorname{mood} ?$ & 0.596 & & & & \\
\hline work? & 0.784 & & & & \\
\hline household activities? & 0.746 & & & & \\
\hline social relationships? & 0.663 & & & & \\
\hline family relationships? & & 0.878 & & & \\
\hline leisure time activities? & 0.597 & & & & \\
\hline ability to function in daily life? & 0.575 & & & & \\
\hline sexual drive, interest and/or performance? & & & & & 0.896 \\
\hline economic status? & & & & 0.793 & \\
\hline living/housing situation? & & 0.884 & & & \\
\hline $\begin{array}{l}\text { ability to get around physically without feeling dizzy or } \\
\text { unsteady or falling? }\end{array}$ & 0.691 & & & & \\
\hline your vision in terms of ability to do work or hobbies? & 0.375 & & & & \\
\hline overall sense of wellbeing? & & & & 0.545 & \\
\hline medication? & & & 0.622 & & \\
\hline $\begin{array}{l}\text { How would you rate your overall life satisfaction and } \\
\text { contentment during the past week? }\end{array}$ & & & 0.562 & & \\
\hline
\end{tabular}


to keep two domains for further research. This twocomponent solution explained the total of $37.80 \%$ of variance, whereby the contribution of the first domain was $27.1 \%$ and the second $10.7 \%$. Very few items had factor weights for the domains 3,4 and 5. This implied that the solution of only two domains was more appropriate. In order to interpret these two domains, orthogonal rotation by Varimax method was conducted. The first domain included the following items: satisfaction with physical health, mood, work, household activities, leisure time activities, abilities to function in daily life, abilities to get around physically without feeling dizzy or unsteady or falling, social relationships, own vision in terms of ability to do work or hobbies. The main factor weights of the domain 1 provide items related to satisfaction with work, household activities and abilities to get around physically without feeling dizzy or unsteady and social relationships. The second domain included the following items: satisfaction with work, living/housing situation, and family relationships. Predominant items in the second domain were satisfaction with living/housing situation, and family relationships. There was poor negative correlation $(r=-0.23)$ between these two domains, which showed that they were not mutually dependent. Table 3 presents the values of information by items and the distribution of items by domains.

\section{Validation}

The validation of questionnaire was done by the panel of psychiatrists at the Institution for Accommodation of Adults "Male Pčelice" Kragujevac. The correlation between the score of Quality of Life Enjoyment and Satisfaction Question-naire Short Form and the score of previously translated World Health Organisation Questionnaire - Short Form was calculated, whereby the coefficient of Spearman linear correlation was $0.5, \mathrm{p}<0.000$.

\section{DISCUSSION}

In this study, psychometric characteristics of the Quality of Life Enjoyment and Satisfaction Questionnaire - Short Form were examined on the group of 153 patients with schizophrenia at the Institution for Accommodation of Adults "Male Pčelice" Kragujevac. The study shows that the scale is reliable and valid, therefore, it can be used in the analysis of QoL. Two domains were determined by factor analysis. The first domain best explained the items related to mental-physical health, while the second one best explained the items related to social health. The results of investigation conducted by Stevanović D. show that this scale reliably measures all domains within the scale, while in our research two domains related to physical and social health were pronounced (13). This statement shows that some domains are more relevant and superior for measuring QoL in comparison to other domains, and that they do not depend on the type of disease or mental state of patients (14).

The correlation between the score of Quality of Life Enjoyment and Satisfaction Questionnaire - Short Form and the score of previously translated World Health Organisation Questionnaire - Short Form shows that the Quality of Life Enjoyment and Satisfaction Questionnaire - Short Form is useful for the assessment of seriousness of the disease in patients with schizophrenia, but these values should be further examined in various psychiatric states (15). Our study shows that this scale is suitable for measuring QoL in both clinical practice and research. The same was proved in other studies which examined reliability of this scale for measuring QoL of patients who suffer from psychiatric diseases (16-18).

Our study revealed two-component solution, which explained $37.80 \%$ variance, whereby the contribution of the first physical domain was $27.1 \%$, while in social domain it was $10.7 \%$. In the study conducted by Stevanovic D. different results were obtained, where psychosocial domain contributed with $27.41 \%$ and physical domain with $9.07 \%$, which explained the total of $46.47 \%$ variance, probably due to the application of angular rotation in the determination of the number of factors which most contributed to the explanation of variance in the set of data (19). When the score of Quality of Life Enjoyment and Satisfaction Questionnaire - Short Form was compared to the score in the other scale in the study conducted by Rossi et al., a high correlation was found between the scores which measured the same characteristics and a low correlation was observed between the scores that measured different characteristics (20). Our study showed a strong correlation between the score of Quality of Life Enjoyment and Satisfaction Questionnaire - Short Form and the score of the previously translated World Health Organization Questionnaire - Short Form, whereby high values of the score of Quality of Life Enjoyment and Satisfaction Questionnaire - Short 
Form were followed by high values of the score of World Health Organization Questionnaire - Short Form.

\section{CONCLUSION}

This study shows that the Quality of Life Enjoyment and Satisfaction Questionnaire - Short Form is suitable for everyday clinical assessment of patients who suffer from schizophrenia. We showed the validity and suitability of the scale for measuring
QoL of this group of patients. Further research should be directed towards the development of this scale for measuring QoL of various groups of patients.

\section{Acknowledgements}

The authors are grateful for the help of medical staff of the Institution for Accommodation of Adults "Male Pčelice", Kragujevac in collecting the patient data. The study was partially financed by grant No 175007 from the Ministry of Education, Republic of Serbia.

\section{References}

1. Jankovic S. Pharmacology and Toxicology. Faculty of Medical Sciences, University of Kragujevac, Kragujevac, 2011: 205-206.

2. Awad AG, Voruganti LN. Measuring quality of life in patients with schizophrenia: an update. Pharmacoeconomics 2012; 30(3): 183-95. http://dx.doi.org/10.2165/11594470-000000000-00000 PMID: 22263841

3. Alshowkan A, Curtis J, White Y. Quality of life for people with schizophrenia: a literature review. Arab J Psychiatry 2012; 23(2): 122-31.

4. The WHOQOL Group. The World Health Organization Quality of Life Assessment (the WHOQOL): position paper from the World Health Organisation. SocSci Med 1995; 41: 1403-9.

http://dx.doi.org/10.1016/0277-9536(95)00112-K

5. Endicott J, Nee J, Harrison W, et al. Quality of Life Enjoyment and Satisfaction Questionnaire: a new measure. Psychopharmacology Bulletin 1993; 29(2): 321-6.

PMid: 8290681

6. Lee YT, Liu SI, Huang HC, Sun FJ, Huang CR, Yeung A. Validity and reliability of the Chinese version of the Short Form of Quality of Life
Enjoyment and Satisfaction Questionnaire (QLES-Q-SF). Qual Life Res 2014; 23(3): 907-16. http://dx.doi.org/10.1007/s11136-013-0528-0 PMid: 24062242

7. Rucci P, Rossi A, Mauri M, et al. Validity and reliability of Quality of Life, Enjoyment and Satisfaction Questionnaire, Short Form. EpidemiolPsichiatrSci 2007; 16: 82-9. PMid: 17427608

8. Hope LM, Page PC,Hooke GR. The value of adding the Quality of Life Enjoyment and Satisfaction Questionnaire to outcome asses sments of psychiatric inpatients with mood and affective disorders. Quality of Life Research 2009; 18: 647-55.

http://dx.doi.org/10.1007/s11136-009-9478-y

PMid: 19418242

9. Majstorovic B, Jankovic S, Dimoski Z, Kekus D, Kocic S, Mijailović Ž. Assessment of the Reliability of the Serbian Version of the Sickness Impact Profile Questionnaire in Patients with Chronic Viral Hepatitis. SrpArhCelokLek 2015; 143(11-12): 688-94. http://dx.doi.org/10.2298/SARH1512688M PMid: 26946763

10. World Health Organization (1993) The ICD-10 
Classification of Mental and Behavioural Disorders - Diagnostic Criteria for Research. World Health Organization, Geneva.

11. Ascione FJ, Kirscht JP, Shimp LA. An assessment of different components of patient medication knowledge. Medical Care 1986; 24(11): 1018-28. http://dx.doi.org/10.1097/00005650-198611000-00006 PMid: 3773576

12. Tabachnich B., Fidell S. Using multivariate statistics, Boston 2007: Pearson Education.

13. Stevanovic D. Quality of Life Enjoyment and Satisfaction Questionnaire - short form for quality of life assessments in clinical practice: a psychometric study. JPsychiatrMent Health Nurs 2011; 18: 744-50.

http://dx.doi.org/10.1111/j.1365-2850.2011.01735.x PMid: 21896118

14. Wyrwich KW, Harnam N, Revicki DA, Locklear JC, Svedsater H, Endicott J. Assessment of quality of life enjoyment and satisfaction questionnaire-short form responder thresholds in generalized anxiety disorder and bipolar disorder studies. Into ClinPsychopharmacol 2011; 26(3): 121-9

http://dx.doi.org/10.1097/YIC.0b013e3283427cd7 PMid: 21164351

15. Ritsner M, Kurs R, Kostizky H, et al. Subjective quality of life in severely mentally illpatients: a comparison of two instruments. Quality of Life Research 2002; 11: 553-61.
http://dx.doi.org/10.1023/A:1016323009671

PMid: 12206576

16. The quality of life enjoyment and satisfaction questionnaire (Q-LES-Q), Latvian language version: Study, validation, and quality of life measurement in posttraumatic stress disorder risk Int JPsychophysiol 2010; 77(3).

17. Rasskazova E. Evaluation of Quality of Life Enjoyment and Satisfaction: Psychometric Properties of a Russian-language Measure. Psychol JHigh School Economics 2012; 9(4): 81-90.

18. Zubaran C, Foresti K, Thorell MR, Franceschini PR, Homero W. Portuguese version of the Quality of Life Enjoyment and Satisfaction Questionnaire: A validation study. Revista Panamericana de SaludPublica 2009; 25(5): 443-8.

http://dx.doi.org/10.1590/s1020-49892009000500010

19. Stevanovic D. Is the Quality of Life Enjoyment and Satisfaction Questionnaire-Short Form (QLES-Q-SF) a unidimensional or bidimensionalin strument? Qual Life Res 2013.

20. Rossi A, Rucci P, Mauri M, Maina G, Pieraccini F, Pallanti S, Endicott J. Validity and reliability of the Italian version of the Quality of Life, Enjoyment and Satisfaction Questionnaire. Qual Life Res 2005; 14(10): 2323-8. http://dx.doi.org/10.1007/s11136-005-7387-2 PMid: 16328911 


\title{
Prevođenje, kulturalno prilagođavanje $i$ ispitivanje pouzdanosti i punovažnosti “Upitnika o kvalitetu života i zadovoljstvu životom - Kratka verzija" za bolesnike sa shizofrenijom
}

\author{
Aleksandra Petrović Kitić, Slobodan Janković \\ Univerzitet u Kragujevcu, Fakultet medicinskih nauka, \\ Departman za farmakologiju i toksikologiju, Kragujevac, Srbija
}

\section{SAŽETAK}

Upitnik o kvalitetu života i zadovoljstvu životom - Kratka verzija je najčešće korišćena skala za merenje kvaliteta života kod pacijenata koji boluju od psihijatrijskih oboljenja. Cilj ovog istraživanja bio je da se na uzorku obolelih od shizofrenije analiziraju mogućnost i merenja kvaliteta života u kliničkim uslovima koristeći ovu skalu. Studija je sprovedena u Zavodu za smeštaj odraslih lica "Male Pčelice” Kragujevac na grupi od 153 pacijenata obolelih od shizofrenije. Studija predstavlja opservacionu studiju tipa studije preseka. Pouzdanost upitnika je ispitana izračunavanjem Kronbahove alfe. Korišćena su dva testa opravdanosti primene faktorske analize: Bartletov test sferičnosti i Kajzer-Mejer-Olkinov pokazatelj adekvatnosti uzorka. Validacija je urađena i izračunavanjem korelacije (validacije prema kriterijumu). Upitnik o kvalitetu života i zadovoljstvu životom - Kratka verzija je pouzdana (Kronbahov koeficijent alfa je 0,730) i validna. Na osnovu Katelovog kriterijuma zadržana su dva domena. To dvokomponentno rešenje objasnilo je ukupno $37,80 \%$ varijanse, pri čemu je doprinos prvog domena $27,1 \%$, a drugog domena $10,7 \%$. Upitnik o kvalitetu života i zadovoljstvu životom - Kratka verzija je pogodna za svakodnevnu, kliničku procenu obolelih od shizofrenije.

Ključne reči: kvalit života, upitnici, kulturalno prilagođavanje, pouzdanost 